\title{
Corrigendum to "Assessment of sediment quality in two important areas of mariculture in the Bohai Sea and the northern Yellow Sea based on acid-volatile sulfide and simultaneously...
}

ARTICLE in MARINE POLLUTION BULLETIN · JULY 2013

Impact Factor: 2.79 · DOI: 10.1016/j.marpolbul.2013.02.007 · Source: PubMed

CITATIONS

15

3 AUTHORS, INCLUDING:

Xuelu Gao

Chinese Academy of Sciences 38 PUBLICATIONS 545 CITATIONS
DOWNLOADS

VIEWS

115
121 
Provided for non-commercial research and education use. Not for reproduction, distribution or commercial use.

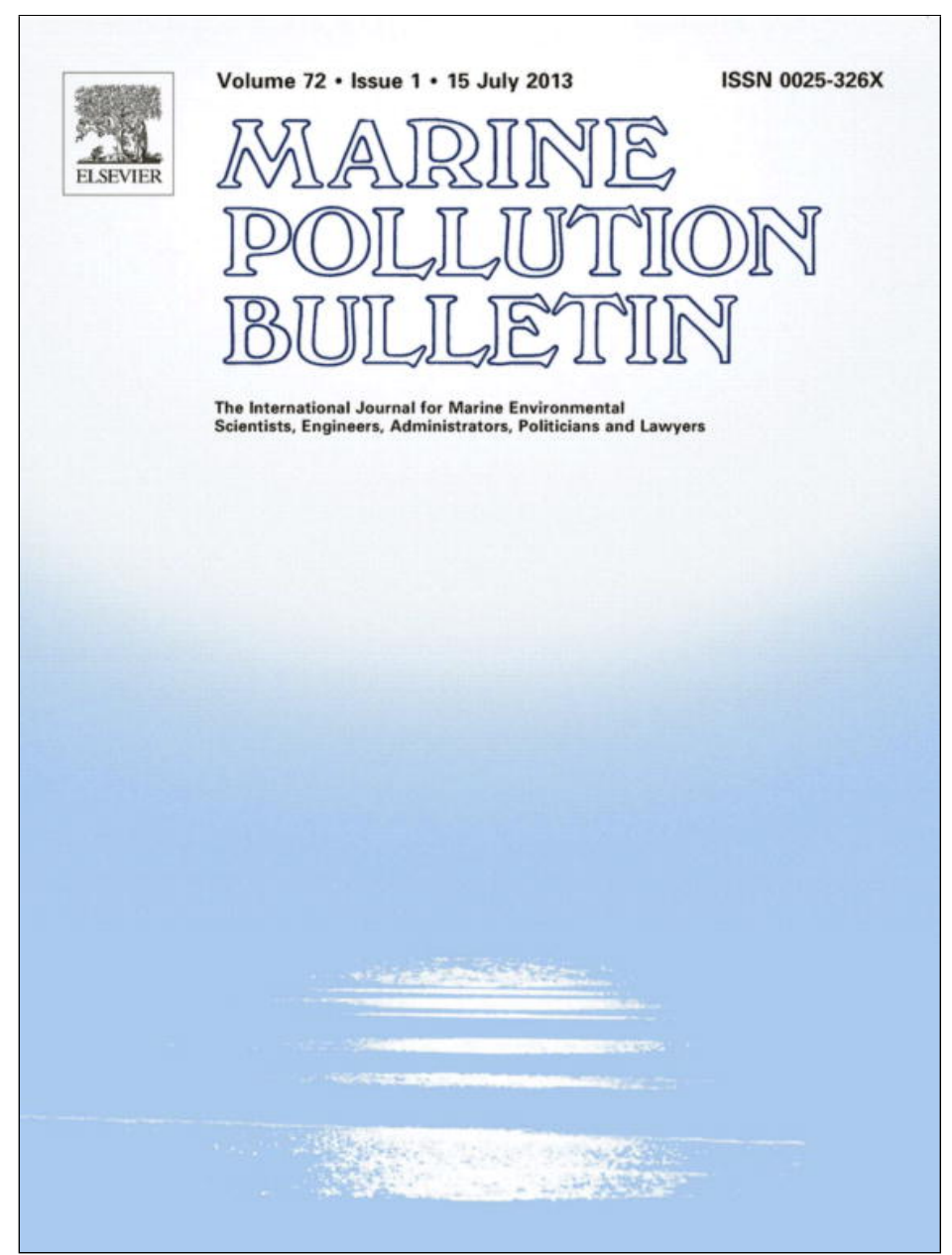

This article appeared in a journal published by Elsevier. The attached copy is furnished to the author for internal non-commercial research and education use, including for instruction at the authors institution and sharing with colleagues.

Other uses, including reproduction and distribution, or selling or licensing copies, or posting to personal, institutional or third party websites are prohibited.

In most cases authors are permitted to post their version of the article (e.g. in Word or Tex form) to their personal website or institutional repository. Authors requiring further information regarding Elsevier's archiving and manuscript policies are encouraged to visit:

http://www.elsevier.com/authorsrights 
Baseline

\title{
Assessment of sediment quality in two important areas of mariculture in the Bohai Sea and the northern Yellow Sea based on acid-volatile sulfide and simultaneously extracted metal results
}

\author{
Xuelu Gao ${ }^{\mathrm{a}, \mathrm{b}, *}$, Peimiao Li ${ }^{\mathrm{a}, \mathrm{c}}$, Chen-Tung Arthur Chen ${ }^{\mathrm{b}}$ \\ ${ }^{a}$ Key Laboratory of Coastal Zone Environmental Processes and Ecological Remediation, Yantai Institute of Coastal Zone Research(YIC), Chinese Academy of Sciences(CAS), Shandong \\ Provincial Key Laboratory of Coastal Zone Environmental Processes, YICCAS, Yantai, Shandong 264003, China \\ ${ }^{\mathrm{b}}$ Institute of Marine Geology and Chemistry, National Sun Yat-Sen University, Kaohsiung 804, Taiwan \\ ${ }^{\mathrm{c}}$ University of the Chinese Academy of Sciences, Beijing 100049, China
}

\section{A R T I C L E I N F O}

\section{Keywords:}

Acid-volatile sulfide

Toxic trace metals

Mobility

Sediment geochemistry

Mariculture area

China

\begin{abstract}
A B S T R A C T
The surface sediments from Laizhou Bay (LB) and the coastal sea around Zhangzi Island (ZI) were analyzed for acid-volatile sulfide (AVS) and simultaneously extracted metals (SEMs) to assess the sediment quality. These two areas, especially LB, are important mariculture bases in China and are significantly affected by the Yellow River. The concentrations of AVS ([AVS]) and SEM ([SEM]) varied in the ranges $0.71-11.03$ and $0.10-0.74 \mu \mathrm{mol} \mathrm{g}^{-1}$ dry weight, respectively. [AVS] was generally low in the river outlet area and increased in the seaward direction in LB. [AVS] was significantly and positively correlated with TOC. [SEM] was significantly and positively correlated with TOC, the water content of sediment and the fine sediment fraction and it was significantly and negatively correlated with coarse sediment fraction. The obtained results suggest that the surface sediments of LB and ZI were of high quality and not likely to cause negative effects on their ecosystems.
\end{abstract}

(c) 2013 Elsevier Ltd. All rights reserved.
In aquatic ecosystems, sediments are the main sinks for trace metal elements. They can also act as a source of trace metals when environmental conditions ( $\mathrm{pH}$, Eh, and others) change (van den Berg et al., 1999; Wilson and Chang, 2000). Trace metals as ubiquitous environmental contaminants are of great concern, because many of them are toxic at concentrations over certain thresholds. One of the most serious environmental problems of these metals, which differentiates them from other toxic pollutants, is that they are resistant to biodegradation and have potential to bioaccumulate and become biomagnified, increasing the exposure of organisms, and even human beings. Therefore, the contents of many trace metals in sediment are determined to provide information for the assessment of environmental health risks (Long et al., 1995; SEPA, 2002).

China is one of the most developed sea farming countries in the world. One of the main farmed species is the benthic filter-feeding shellfish, the quality of which is closely related to the marine sediments. Laizhou Bay in Shandong province and Zhangzi Island in Liaoning province contribute considerably to the seafood production

\footnotetext{
* Corresponding author at: Key Laboratory of Coastal Zone Environmental Processes and Ecological Remediation, Yantai Institute of Coastal Zone Research, Chinese Academy of Sciences, Shandong 264003, China. Tel.: +86 535 2109132; fax: +865352109000.

E-mail address: xlgao@yic.ac.cn (X. Gao).
}

in China. Enriched by large amounts of river-borne nutrients, Laizhou Bay supports large populations of marine organisms and is traditionally an important fishing ground in North China. In the past few decades, industrial and urban development around the bay has proceeded quickly: huge amounts of trace metals accompany domestic sewage and industrial wastewater that are directly discharged into Laizhou Bay, causing pollution by trace metals to become one of the most serious environmental crises of the bay. Located in the Yellow Sea, far away from the mainland, Zhangzi Island is usually taken for granted as a sea farming base with a satisfactory environment that lacks land-derived contaminants.

The availability of metal for bioaccumulation has been verified to be related to mechanisms of binding onto total organic carbon (TOC) in oxic sediments (Yu et al., 2001). The availability of divalent metals to organisms that live nearby has been related to the amount of acid-volatile sulfide (AVS) in anoxic sediments (Di Toro et al., 1990, 1992; Ankley et al., 1996; Cooper and Morse, 1998). As one of the major chemical constituents of marine sediments, AVS plays an important role in controlling the activities and availability of metals in the interstitial waters of sediments (Prica et al., 2008). Several divalent transition metal cations, which are mainly cadmium $(\mathrm{Cd})$, copper $(\mathrm{Cu})$, lead $(\mathrm{Pb})$, nickel $(\mathrm{Ni})$ and zinc $(\mathrm{Zn})$, can react with sulfides to form highly insoluble metal sulfides that are not bioavailable (Di Toro et al., 1992; Allen et al., 1993; Ankley et al., 1996; Berry et al., 1996; USEPA, 2004). 
AVS is operationally defined as the amount of sulfide that can be volatilized by cold acid extraction. The sulfide-bound metals that were extracted during this process at the same time are called "simultaneously extracted metals" (SEMs). Divalent transition metals have been proven not to cause toxicity in sediment until their molar concentrations exceed that of sulfide (Di Toro et al., 1990). In environmental research, the molar concentration of AVS ([AVS], $\mu \mathrm{mol} \mathrm{g}^{-1}$ ) is usually compared to the sum of the molar concentrations of five metals - $\mathrm{Cd}, \mathrm{Cu}, \mathrm{Ni}, \mathrm{Pb}$ and $\mathrm{Zn}-$ ([SEM], $\mu \mathrm{mol} \mathrm{g}^{-1}$ ) to evaluate the potential effects of those metals on benthic species. A consensus exists that the potential mobility and toxicity of trace metals in sediment are not related to their total contents but directly related to the [SEM]/[AVS] ratio of the sediment (Di Toro et al., 1992; Berry et al., 1996; USEPA, 2001, 2004). Trace metal ions may exhibit no acute toxicity toward organisms that live in nearby sediment when [SEM]/[AVS] is $<1$, even if the absolute SEM concentration is high; on the contrary, the sediment may be potentially toxic when this ratio is $>1$ (Ankley et al., 1996; Di Toro et al., 1990).

In China, studies on toxic trace metals and the quality of marine sediment have been carried out mainly in coastal areas that suffer from strong anthropogenic effects from the surroundings, such as the coastal Bohai Bay (e.g. Gao and Chen, 2012; Gao and Li, 2012). Ideally, mariculture areas should be as far as possible from anthropogenic pollution, but all over the world, including in China, locating them at large distances is basically impossible at present in heavily populated coastal areas. Hence, to keep abreast of the information on the quality of sediment in mariculture areas is even more important compared with other marine areas, because its quality directly affects the quality of mariculture products and thereby indirectly affects the health of human beings. Although AVS and SEM are good environmental indicators, the publicly available literature contains no information about them for sediments of the Laizhou Bay and the coastal sea around Zhangzi Island. Given the importance of Laizhou Bay and Zhangzi Island in the mariculture industry of China, information about the mobility/bioavailability of trace metals in sediments and on the impact of these metals on marine biota in these two areas is urgently needed. The aim of this study is to assess the quality of sediment based on analyzes of AVS and SEM in the surface sediments of these two mariculture areas in China.

The surveys in this study were carried out in two phases in 2011 - October 27th-30th for Laizhou Bay and November 11th-16th for the coastal sea that surrounds Zhangzi Island (hereafter referred to as Zhangzi Island for short). Eighteen grid stations are located in Laizhou Bay and seven scatter stations are located in Zhangzi Island (Fig. 1). Stations L1 and L6 were near to the new and old mouths of the Yellow River; station L18 was near to the estuary of the Xiaoqinghe River; stations Z1 to Z3 were located in the intertidal zone of Zhangzi Island; stations Z4 to Z6 were in the coastal area of the island, and of these $\mathrm{Z} 4$ and $\mathrm{Z} 5$ were located in the mariculture areas of Zhangzi Island in which Apstichopus japonicus and Patinopecten yessoensis were farmed. All materials that were utilized for sampling, treatment and storage were carefully chosen and properly treated to minimize anthropogenic contamination of the samples externally (USEPA, 2004). Sampling was carried out using a stainless steel grab sampler and/or a plastic spatula. One sample was collected at each sampling station and a total of 25 surface $(0-5 \mathrm{~cm})$ sediment samples were obtained. Immediately after being taken, each sample was packed in a new polyethylene zipper bag that was full of high-purity nitrogen gas $\left(\mathrm{N}_{2}\right)$, transported to the laboratory in a cooler box with ice packs and stored in a refrigerator at $4{ }^{\circ} \mathrm{C}$ for future analyzes.

AVS and SEM were determined by combining and optimizing the methods of Hsieh and Yang (1989), Allen et al. (1993) and Brouwer and Murphy (1994), within 2 weeks after sample collection (Lasorsa and Casas, 1996). The experimental setup involved a $250 \mathrm{ml}$ three-necked flask in which the reaction was conducted; the flask was sequentially connected to two $250 \mathrm{ml}$ scrubbing bottles, each of which contained $100 \mathrm{ml}$ of $0.5 \mathrm{~mol} \mathrm{l}^{-1}$ zinc acetate solution to trap the evolved gases. The experimental apparatus was purged for $20 \mathrm{~min}$ with high-purity $\mathrm{N}_{2}$ at a flow rate of

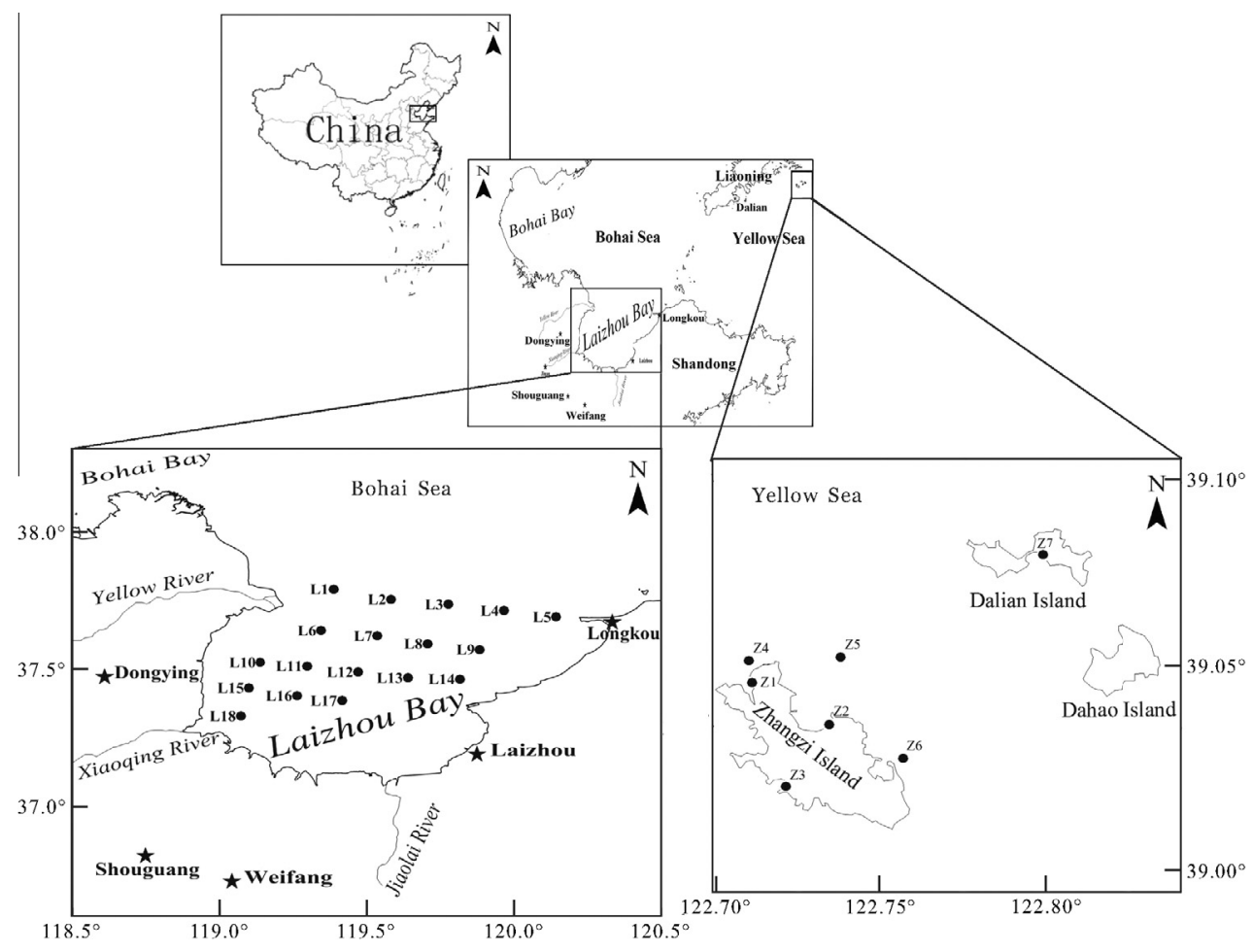

Fig. 1. Locations of sampling sites in Laizhou Bay and coastal sea around Zhangzi Island, China. 
$60 \mathrm{ml} \mathrm{min}{ }^{-1}$ to squeeze out internal oxygen. About $5 \mathrm{~g}$ of a wet sediment sample was added to the reaction vessel. The threenecked flask was purged with $\mathrm{N}_{2}$ at a flow rate of $20 \mathrm{ml} \mathrm{min}^{-1}$ while $50 \mathrm{ml}$ of $\mathrm{HCl}(1+1)$ solution was injected quickly to initiate the reaction. The sediment suspension was stirred for at least 50 min while purging with $\mathrm{N}_{2}$ at a flow rate of $60 \mathrm{ml} \mathrm{min}^{-1}$ at room temperature to release $\mathrm{H}_{2} \mathrm{~S}$, which was subsequently collected in trapping vessels. The concentrations of dissolved sulfides in the absorbed liquid were measured using iodine as an oxidant (Hsieh and Shieh, 1997). After the resulting sediment suspension had been filtered through a $0.45 \mu \mathrm{m}$ membrane, concentrations of $\mathrm{Cd}, \mathrm{Cu}, \mathrm{Ni}$, $\mathrm{Pb}$, and $\mathrm{Zn}$ in the filtrate were determined by inductively coupled plasma optical emission spectrometry (ICP-OES, Perkin-Elmer Optima 7000DV, USA) to provide [SEM] data. All results were expressed with respect to the dry weight of the sediment.

Apparatus blanks, calibration curves, reagent blanks and standard recoveries were employed in the analysis. Duplicate measurements were made and the relative standard deviations of the AVScontent and SEM-content were less than $10 \%$. The recovery rate of the experimental method was checked using a sodium sulfide solution with a known concentration and it appeared to be better than $90 \%$.

All glass and plastic wares that were used in the measurement were pre-cleaned by soaking in $5 \% \mathrm{HNO}_{3}(\mathrm{v} / \mathrm{v})$ for at least $48 \mathrm{~h}$, followed by soaking and rinsing with Milli-Q deionized water. All of the chemicals were guaranteed-reagent grade or better, and all experimental solutions were made using deoxygenated Milli-Q water.

The granularity of each sample was analyzed using a Malvern Mastersizer 2000 laser diffractometer with the ability to analyze particles with sizes between 0.02 and $2000 \mu \mathrm{m}$. The percentages of particles that fell into the following three size ranges were determined; <4 $\mu \mathrm{m}$ (clay), 4-63 $\mu \mathrm{m}$ (silt), and >63 $\mu \mathrm{m}$ (sand).

The water content of the sediments was determined gravimetrically by comparing the weights before and after heating an aliquot at $105^{\circ} \mathrm{C}$ and repeating the post-heating measurements until a constant weight was obtained. The percentages of water were used to convert the substance contents of the sediments from a wet basis to a dry weight basis. The TOC in sediments was analyzed by an Elementar Vario MACRO Cube CHNS analyzer on decarbonated sediments.

In this study, water content, grain sizes, and TOC concentration were measured to obtain the general characteristics of the surface sediment samples for correlation analysis. As displayed in Fig. 2a, the percentages of water content in the surface sediments of Laizhou Bay and Zhangzi Island varied within $22.2-48.4 \%$ and $23.3-$ $35.2 \%$, respectively, with the average values of $33.8 \%$ and $28.3 \%$.

The ternary diagram in Fig. 3 categorized the sediments of Laizhou Bay and Zhangzi Island using the system of Shepard (1954). It reveals that the texture of the sediments of Laizhou Bay and

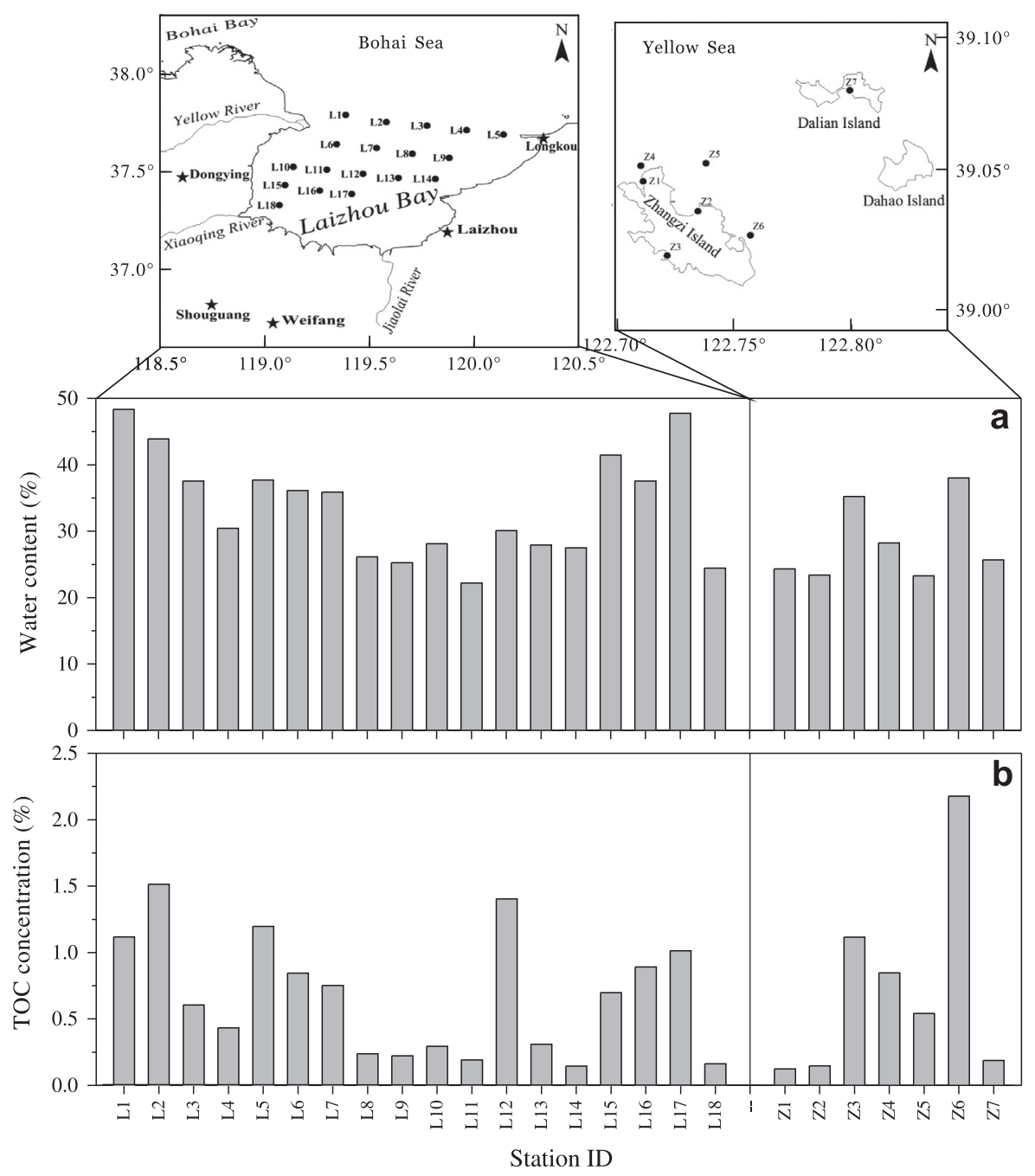

Fig. 2. Spatial variation of water content (a) and TOC concentration (b) in surface sediments of Laizhou Bay and coastal sea around Zhangzi Island. 


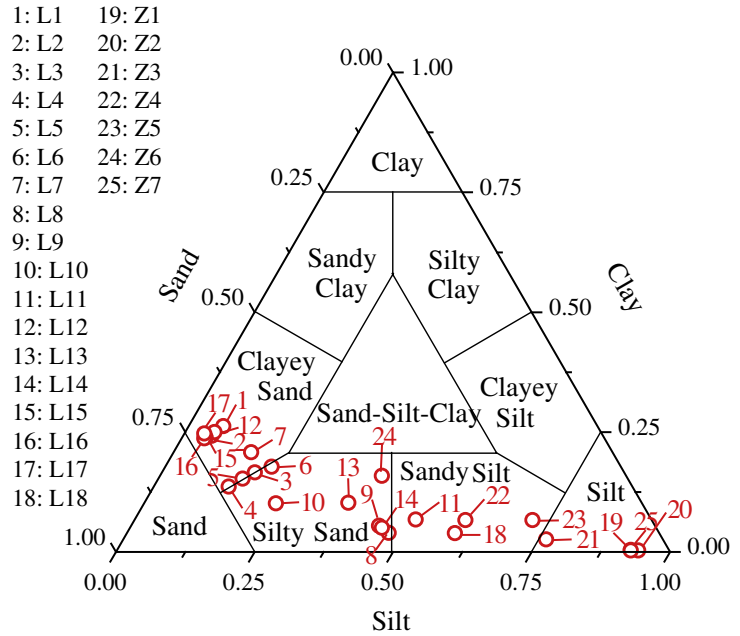

Fig. 3. Ternary diagram showing Shepard's classification and sediment deposition patterns.

Zhangzi Island exhibited clear spatial patterns. Except at the two westernmost sampling locations of L11 and L18, the studied surface sediments of Laizhou Bay were predominantly composed of clayey sand and silty sand; sandy silt dominated samples L11 and L18. The surface sediments of Zhangzi Island, except for sample Z6, were dominated by silt and sandy silt; sample Z6 was predominantly composed of silty sand.

The studied surface sediments were characterized by inhomogeneous concentrations of TOC that constituted $0.12-2.18 \%$ of the dry weight of the sediment with an average of $0.69 \%$ (Fig. 2b). The highest TOC contents were recorded at site L2 in Laizhou Bay and site Z6 in Zhangzi Island. The variation in TOC content among the sediment samples was significant. The TOC contents in sediments with coarser components were relatively lower.

Fig. 4a presents the AVS concentrations in the surface sediment samples of Laizhou Bay and Zhangzi Island. Generally, the AVS concentration increased in the direction from the river outlet or land to the sea, which finding was consistent with the report of Fang et al. (2005), perhaps partly because of the discharge of suspended sediment from surrounding runoff and rivers; marine sediment usually contains more sulfate than does freshwater sediment, and sulfate reduction is a key process in AVS formation in marine sediment (Balzer, 1989; Hansen et al., 1996a; van den Berg et al., 1999).

The AVS concentrations of the sediments from Laizhou Bay varied within the range of $1.22-7.60 \mu \mathrm{mol} \mathrm{g}^{-1}$, averaging $2.99 \mu \mathrm{mol} \mathrm{g}^{-1}$, with the highest and lowest values recorded at stations L5 and L15, respectively. Relatively low AVS concentrations of $<1.50 \mu \mathrm{mol} \mathrm{g}^{-1}$ were detected in three sediments from L5, L9 and L10. About one third of the samples had an AVS level of $>3 \mu \mathrm{mol} \mathrm{g}^{-1}$. Hence these sediments were able to bind trace metals in larger quantities than the others.

The mean AVS concentration in the sediments of Zhangzi Island was $4.05 \mu \mathrm{mol} \mathrm{g}{ }^{-1}$. The lowest and highest concentrations of AVS were 0.71 and $11.03 \mu \mathrm{mol} \mathrm{g}^{-1}$, respectively, which were found in the samples from Z1 (intertidal zone) and Z4 (mariculture area for Apstichopus japonicus). Relatively low AVS concentrations of $<1.50 \mu \mathrm{mol} \mathrm{g}^{-1}$ were obtained in the three sediments from the intertidal zone (Z1, Z2 and Z7). Sediment from Z4 was able to bind trace metals in larger quantities than did the others as reflected by the fact that it had the highest AVS concentration of this study.

The AVS concentration of sediment is a product of the equilibrium between the generation and loss of sulfide as a result of oxidation or diffusion (Lasorsa and Casas, 1996; Oehm et al., 1997).
Therefore, the AVS content in sediment may vary with the factors that affect the rate of sulfate reduction, the sediment redox status and other variables (Oehm et al., 1997; Prica et al., 2008). Table 1 presents the correlation matrix for the sediment components. Unlike clay, silt, sand and water content, the concentration of organic matter may be a major controlling factor for AVS content in the surface sediment of Laizhou Bay and Zhangzi Island, because AVS concentration was significantly and positively correlated with TOC.

Table 2 presents amounts of AVS in the surface sediments that were collected from Laizhou Bay and Zhangzi Island, and corresponding values that were taken from the publicly available literatures on surface sediments in other coastal areas of China. The AVS concentrations in this study varied in a range that was comparable with the range of values that have been reported in the literature for the marine sediments in Bohai Bay (Jiang et al., 2005), Rushan Bay (Wang et al., 2008) and Jiaozhou Bay (Huo et al., 2001); was narrower than the range of values for sediments in the Licunhe Estuary (Yu et al., 2009), Jinzhou Bay (Hansen et al., 1996a), Shen'ao Bay (Du et al., 2011) and the southern continental slope of the East China Sea (Lin et al., 2002) and wider than the range of values for sediments in the Shanghai coastal zone (Sun et al., 2010), Huanghe (Yellow River) Estuary (Wu et al., 2007), Yangtze River Estuary (Sun et al., 2009) and Pearl River Estuary (Fang et al., 2005).

The sum of $\mathrm{Cd}, \mathrm{Cu}, \mathrm{Ni}, \mathrm{Pb}$ and $\mathrm{Zn}$ concentrations, namely [SEM], was in the range $0.10-0.74 \mu \mathrm{mol} \mathrm{g}^{-1}$ (Fig. $4 \mathrm{~b}$ ). The highest and lowest [SEM] values in the Laizhou Bay sediments, found in the samples from L1 and L18, were 0.74 and $0.20 \mu \mathrm{mol} \mathrm{g}^{-1}$, respectively, with an average of $0.45 \mu \mathrm{mol} \mathrm{g}^{-1}$. The highest and lowest [SEM] in the sediments from Zhangzi Island, which were recorded in samples from $\mathrm{Z} 3$ and $\mathrm{Z} 2$, were 0.57 and $0.10 \mu \mathrm{mol} \mathrm{g}^{-1}$, respectively, with an average of $0.32 \mu \mathrm{mol} \mathrm{g}^{-1}$.

As shown in Table 2, [SEM] in the sediments of Laizhou Bay and Zhangzi Island were low, as revealed by comparison with the [SEM] in surface sediments from Chinese coastal areas. The highest [SEM] value that was obtained in this study was $0.74 \mu \mathrm{mol} \mathrm{g}^{-1}$, which was apparently lower than those obtained in other studies: [SEM] in Jinzhou Bay was up to $374 \mu \mathrm{mol} \mathrm{g}^{-1}$ (Hansen et al., 1996a); in Huanghe Estuary, it was $1.86 \mu \mathrm{mol} \mathrm{g}^{-1}$ (Wu et al., 2007); in Bohai Bay, it was $2.96 \mu \mathrm{mol} \mathrm{g}^{-1}$ (Jiang et al., 2005); in Pearl River Estuary, it was $2.65 \mu \mathrm{mol} \mathrm{g}^{-1}$ (Fang et al., 2005), and in Yangtze Estuary, it was $1.37 \mu \mathrm{mol} \mathrm{g}^{-1}$ (Sun et al., 2009).

The concentrations of clay, silt, sand, TOC and water content of the sediments were all significantly correlated with [SEM], revealing that they were potentially influencing factors for the spatial distribution of [SEM] (Table 1). More fine sediment fractions (clay + silt), higher TOC and higher water content and less of the coarse sediment fraction (sand) favored the accumulation of SEM in the surface sediments of Laizhou Bay and Zhangzi Island. No significant correlation existed between [AVS] and [SEM] $(P>0.05)$ indicating their different spatial distribution patterns.

The predominance of $\mathrm{Cu}$ and $\mathrm{Zn}$ over all the other acid-extracted metals was evident in all samples (Fig. 5). These two elements accounted for an average of $\sim 74 \%$ of [SEM], whereas the much more toxic Cd contributed much less than $1 \%$ to [SEM]. On average, in the surface sediments of both Laizhou Bay and Zhangzi Island, the concentrations of the acid-extracted trace metal increased in the order $\mathrm{Cd}<\mathrm{Pb}<\mathrm{Ni}<\mathrm{Cu}<\mathrm{Zn}$. This order was inconsistent with the order of their corresponding total concentrations in the surface sediments of Laizhou Bay (Hu et al., 2012), and the chemical properties of metal sulfides were no doubt an important factor of being responsible for this inconsistence. Metal sulfides have different solubility reflected by the sequence of their $\mathrm{p} K_{\mathrm{sp}}$ values $\mathrm{CuS}>\mathrm{CdS}>\mathrm{PbS}>\mathrm{ZnS}>\mathrm{NiS}$, which largely affects the ability of metals in sediment to form SEM. Besides, the following biogeochemical factors may also contribute to this inconsistence: 


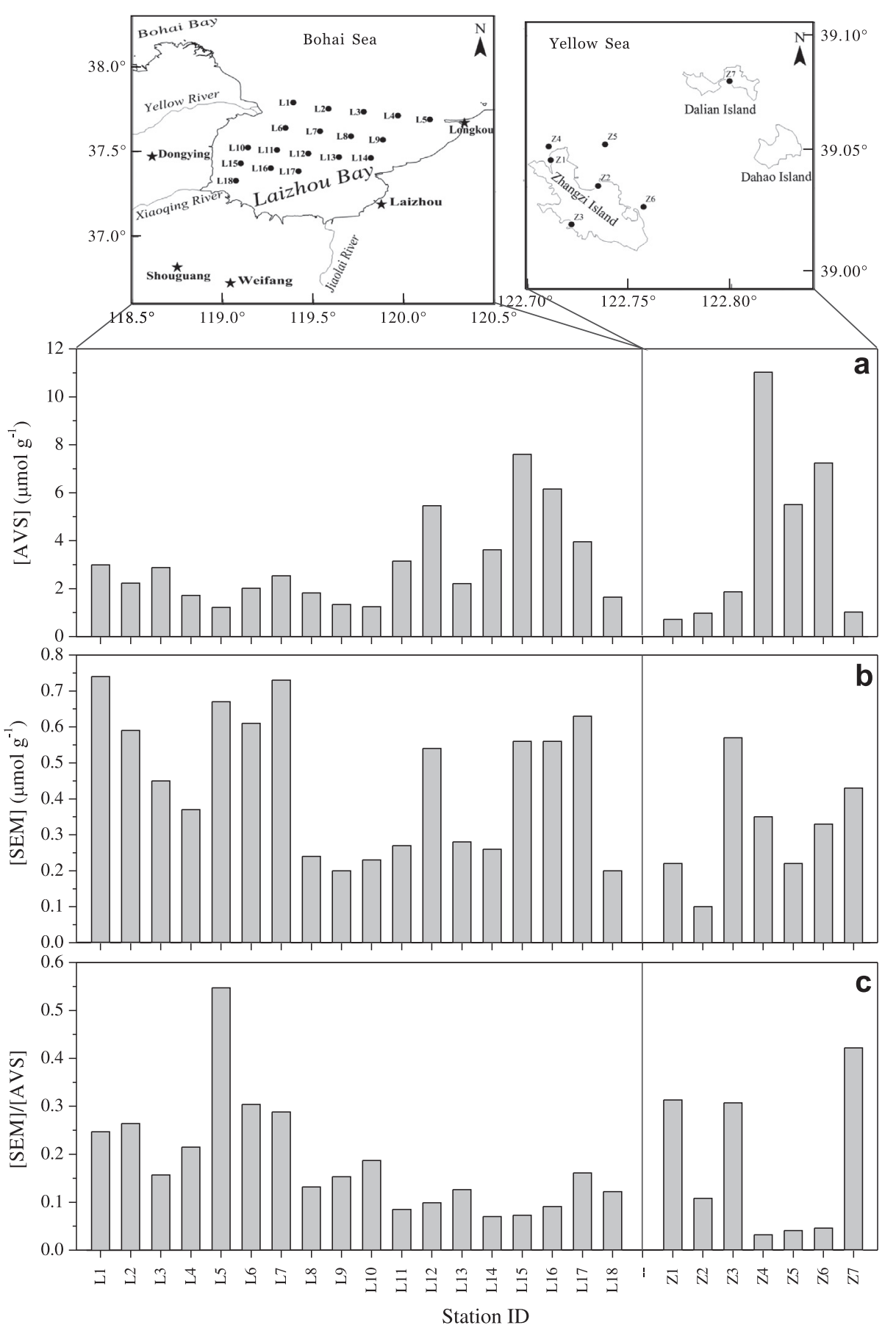

Fig. 4. Spatial variation of [AVS] (a), [SEM] (b) and [SEM]/[AVS] (c) in surface sediments of Laizhou Bay and coastal sea around Zhangzi Island.

Table 1

Pearson correlation coefficients between the measured parameters of surface sediment samples.

\begin{tabular}{|c|c|c|c|c|c|c|c|c|c|c|c|c|}
\hline & [AVS] & [SEM] & $\mathrm{Cd}$ & $\mathrm{Cu}$ & $\mathrm{Ni}$ & $\mathrm{Pb}$ & $\mathrm{Zn}$ & \%Clay & $\%$ Silt & \%Sand & $\%$ TOC & \%Water content \\
\hline [AVS] & 1 & 0.121 & 0.032 & 0.028 & 0.109 & 0.194 & 0.198 & 0.328 & 0.148 & -0.206 & $0.435^{c}$ & 0.202 \\
\hline [SEM] & 0.121 & 1 & $0.794^{a}$ & $0.967^{\mathrm{a}}$ & $0.894^{\mathrm{a}}$ & $0.861^{\mathrm{a}}$ & $0.916^{\mathrm{a}}$ & $0.771^{\mathrm{a}}$ & $0.575^{\mathrm{b}}$ & $-0.652^{\mathrm{a}}$ & $0.605^{\mathrm{b}}$ & $0.836^{\mathrm{a}}$ \\
\hline $\mathrm{Cd}$ & 0.032 & $0.794^{\mathrm{a}}$ & 1 & $0.760^{\mathrm{a}}$ & $0.843^{\mathrm{a}}$ & $0.640^{\mathrm{a}}$ & $0.681^{\mathrm{a}}$ & $0.820^{\mathrm{a}}$ & $0.830^{\mathrm{a}}$ & $-0.856^{\mathrm{a}}$ & 0.378 & $0.712^{\mathrm{a}}$ \\
\hline $\mathrm{Cu}$ & 0.028 & $0.967^{\mathrm{a}}$ & $0.760^{\mathrm{a}}$ & 1 & $0.830^{\mathrm{a}}$ & $0.873^{\mathrm{a}}$ & $0.802^{\mathrm{a}}$ & $0.728^{\mathrm{a}}$ & $0.513^{\mathrm{b}}$ & $-0.594^{\mathrm{b}}$ & $0.519^{\mathrm{b}}$ & $0.810^{\mathrm{a}}$ \\
\hline $\mathrm{Ni}$ & 0.109 & $0.894^{\mathrm{a}}$ & $0.843^{\mathrm{a}}$ & $0.830^{\mathrm{a}}$ & 1 & $0.680^{\mathrm{a}}$ & $0.792^{\mathrm{a}}$ & $0.834^{\mathrm{a}}$ & $0.757^{\mathrm{a}}$ & $-0.806^{\mathrm{a}}$ & $0.485^{\mathrm{c}}$ & $0.736^{a}$ \\
\hline $\mathrm{Pb}$ & 0.194 & $0.861^{\mathrm{a}}$ & $0.640^{\mathrm{a}}$ & $0.873^{\mathrm{a}}$ & $0.680^{\mathrm{a}}$ & 1 & $0.691^{\mathrm{a}}$ & $0.712^{\mathrm{a}}$ & $0.422^{\mathrm{c}}$ & $-0.522^{\mathrm{b}}$ & $0.671^{\mathrm{a}}$ & $0.790^{\mathrm{a}}$ \\
\hline $\mathrm{Zn}$ & 0.198 & $0.916^{\mathrm{a}}$ & $0.681^{\mathrm{a}}$ & $0.802^{\mathrm{a}}$ & $0.792^{\mathrm{a}}$ & $0.691^{\mathrm{a}}$ & 1 & $0.636^{a}$ & $0.481^{\mathrm{c}}$ & $-0.543^{\mathrm{b}}$ & $0.619^{\mathrm{a}}$ & $0.745^{\mathrm{a}}$ \\
\hline
\end{tabular}

a $P<0.001$.

b $0.001<P<0.01$.

c $0.01<P<0.05$. 
Table 2

Summary of [AVS], [SEM] and acid-extracted metal contents in surface sediments collected from Laizhou Bay and Zhangzi Island. Related values reported for surface sediments of other coastal areas of China are shown for comparison. The unit is $\mu \mathrm{mol} \mathrm{g}^{-1}$ dry sediment weight for all parameters.

\begin{tabular}{|c|c|c|c|c|c|c|c|c|c|}
\hline Location & & [AVS] & [SEM] & $\mathrm{Cd}$ & $\mathrm{Cu}$ & $\mathrm{Ni}$ & $\mathrm{Pb}$ & $\mathrm{Zn}$ & Reference \\
\hline \multirow[t]{2}{*}{ Laizhou Bay } & Range & $1.22-7.60$ & $\begin{array}{l}0.20- \\
0.74\end{array}$ & $\begin{array}{l}0.0011- \\
0.0033\end{array}$ & $\begin{array}{l}0.051- \\
0.310\end{array}$ & $\begin{array}{l}0.033- \\
0.138\end{array}$ & $\begin{array}{l}0.014- \\
0.097\end{array}$ & $\begin{array}{l}0.064- \\
0.278\end{array}$ & \multirow[t]{2}{*}{ Present study } \\
\hline & Mean & 2.99 & 0.45 & 0.0020 & 0.166 & 0.074 & 0.044 & 0.165 & \\
\hline \multirow[t]{2}{*}{ Zhangzi Island } & Range & $\begin{array}{l}0.71- \\
11.03\end{array}$ & $\begin{array}{l}0.10- \\
0.57\end{array}$ & BDL-0.0013 & $\begin{array}{l}0.026- \\
0.247\end{array}$ & $\begin{array}{l}0.013- \\
0.046\end{array}$ & $\begin{array}{l}0.010- \\
0.067\end{array}$ & $\begin{array}{l}0.052- \\
0.216\end{array}$ & \multirow[t]{2}{*}{ Present study } \\
\hline & Mean & 4.05 & 0.32 & 0.0007 & 0.109 & 0.034 & 0.039 & 0.137 & \\
\hline $\begin{array}{l}\text { Southern East China Sea continental } \\
\text { slope }\end{array}$ & Range & $0-25$ & ND & ND & ND & ND & ND & ND & Lin et al. (2002) \\
\hline \multirow[t]{2}{*}{ Huanghe Estuary } & Range & $0.15-1.85$ & $\begin{array}{l}0.90- \\
1.86\end{array}$ & $0.184-0.376$ & $\begin{array}{l}0.212- \\
0.404\end{array}$ & ND & $\begin{array}{l}0.017- \\
0.033\end{array}$ & $\begin{array}{l}0.438- \\
1.228\end{array}$ & \multirow[t]{2}{*}{ Wu et al. (2007) } \\
\hline & Mean & 0.94 & 1.33 & 0.022 & 0.289 & ND & 0.230 & 0.764 & \\
\hline Jinzhou Bay & Range & $3.02-126$ & $2.9-374$ & ND & ND & ND & ND & ND & $\begin{array}{l}\text { Hansen et al. } \\
(1996 a)\end{array}$ \\
\hline \multirow[t]{2}{*}{ Jiaozhou Bay } & Range & $\begin{array}{l}5.06- \\
19.11\end{array}$ & ND & ND & ND & ND & ND & ND & \multirow[t]{2}{*}{ Huo et al. (2001) } \\
\hline & Mean & 11.41 & ND & ND & ND & ND & ND & ND & \\
\hline Licunhe Estuary, Jiaozhou Bay & Range & $\begin{array}{l}0.43- \\
29.45\end{array}$ & ND & ND & ND & ND & ND & ND & Yu et al. (2009) \\
\hline \multirow[t]{2}{*}{ North area of the Bohai Bay } & Range & $\begin{array}{l}1.02- \\
13.68\end{array}$ & $\begin{array}{l}1.92- \\
2.96\end{array}$ & $0.01-0.22$ & $0.43-0.63$ & ND & $0.31-0.78$ & $1.01-1.52$ & \multirow[t]{2}{*}{ Jiang et al. (2005) } \\
\hline & Mean & 3.43 & 2.22 & 0.05 & 0.53 & ND & 0.43 & 1.22 & \\
\hline \multirow[t]{2}{*}{ Pearl River Estuary } & Range & $\begin{array}{l}<0.01- \\
3.89\end{array}$ & $\begin{array}{l}1.12- \\
2.65\end{array}$ & $0.034-0.057$ & $0.22-0.42$ & $0.22-0.32$ & $0.13-0.24$ & $0.35-1.42$ & \multirow[t]{2}{*}{ Fang et al. (2005) } \\
\hline & Mean & 1.59 & 1.95 & 0.043 & 0.31 & 0.29 & 0.18 & 0.94 & \\
\hline Rushan Bay & Range & $0.94-8.94$ & ND & ND & ND & ND & ND & ND & Wang et al. (2008) \\
\hline \multirow[t]{2}{*}{ Shanghai coastal zone } & Range & $0.02-5$ & ND & ND & ND & ND & ND & ND & \multirow[t]{2}{*}{ Sun et al. (2010) } \\
\hline & Mean & 0.56 & ND & ND & ND & ND & ND & ND & \\
\hline Shen'ao Bay & Range & $\begin{array}{l}0.04- \\
39.09\end{array}$ & ND & ND & ND & ND & ND & ND & Du et al. (2011) \\
\hline \multirow[t]{2}{*}{ Yangtze River Estuary } & Range & $0.20-0.80$ & $\begin{array}{l}0.20- \\
1.37\end{array}$ & $\begin{array}{l}0.0012- \\
0.0060\end{array}$ & $0.02-0.91$ & $0.15-0.41$ & $0.02-0.21$ & ND & \multirow[t]{2}{*}{ Sun et al. (2009) } \\
\hline & Mean & 0.23 & 0.74 & 0.0031 & 0.36 & 0.26 & 0.12 & ND & \\
\hline
\end{tabular}

BDL: below detection limit.

ND: no data.

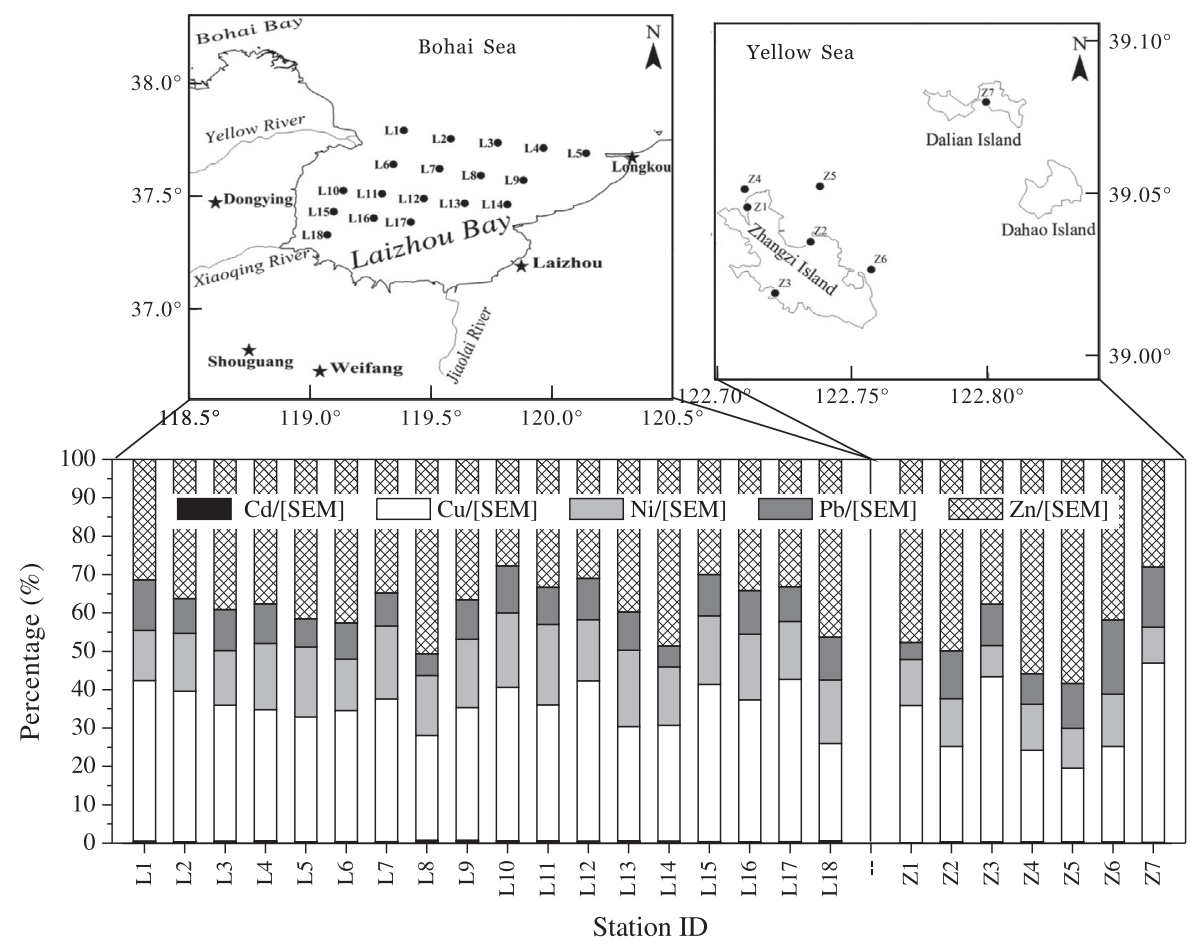

Fig. 5. Spatial distribution of relative contents of SEM components in surface sediments of Laizhou Bay and coastal sea around Zhangzi Island. 
the sediment type on the basis of the parameters that affect metal interaction with sediment matrix, basically $\mathrm{pH}$, cationic exchange capacity, nutrient status, carbonates and organic matter contents, redox potential and texture; the environmental conditions that may lead to weathering, such as acidification, redox processes, temperature and water regime. The percentage contributions of $\mathrm{Cd}, \mathrm{Pb}, \mathrm{Ni}, \mathrm{Cu}$ and $\mathrm{Zn}$ to [SEM] varied in the ranges of $0-0.68 \%$, $4.4-19.3 \%, 8.1-21 \%, 19.3-46.8 \%$ and $27.7-58.4 \%$ with average values of $0.4 \%, 10.3 \%, 15.2 \%, 34.4 \%$ and $39.8 \%$, respectively. The order of the relative percentages of the components of SEM in the surface sediments of Laizhou Bay and Zhangzi Island were identical to those of the Pearl River Estuary (Table 2).

The significant correlations in Table 1 indicate that the grain size distribution, TOC content and water content probably played important roles in controlling the behaviors of every acid-extracted metal in the surface sediments of Laizhou Bay and Zhangzi Island. The significant correlations among the concentrations of all studied metals suggest that these metals in the sediments had a common origin (Table 1), such as discharged wastewater, especially from industrial sources (Liu et al., 2004; Wang and Wang, 2007; Hu et al., 2012). Their correlations appeared to reveal that the clay sediment fraction and TOC appeared to significantly affect the concentrations of $\mathrm{Pb}$ and $\mathrm{Zn}$, while the concentrations of $\mathrm{Cd}, \mathrm{Cu}$ and $\mathrm{Ni}$ appeared to be more strongly influenced by the grain size distribution in the sediments than by the TOC content (Table 1 ).

Numerous studies have demonstrated that the dry weight concentrations of metals in sediments alone do not suffice for the evaluation of bioavailability/toxicity or pollution status across sediments (Luoma, 1989; Di Toro et al., 1990). Many studies have shown that the [SEM]/[AVS] ratio can be used as an indicator of the degree of pollution of sediment by $\mathrm{Cd}, \mathrm{Cu}, \mathrm{Ni}, \mathrm{Pb}$, and $\mathrm{Zn}$ for a wide range of sediment types that involve freshwater and seawater (e.g. Ankley et al., 1994; Berry et al., 1996; Hansen et al., 1996b). According to the Di Toro et al. (1992), when [SEM]/[AVS] is $<1$, which was the case for all samples in this study, no acute toxic effects of metals in sediments are expected. As shown in Fig. 4c, the [SEM]/[AVS] ratios in the surface sediments of Laizhou Bay and Zhangzi Island were within the ranges $0.07-0.55$ and $0.03-0.42$ with averages of $0.18 \pm 0.12$ and $0.18 \pm 0.16$ (mean \pm standard deviation), respectively. These values were far less than the value indicating that the sediments may have potential negative effects on surrounding ecosystem, namely [SEM]/[AVS] $>1$ (Di Toro et al., 1992; Berry et al., 1996).

Theoretically, nickel sulfide is the most water-soluble of the sulfide compounds of the five metals that were studied herein. It is followed by zinc sulfide, based on the solubility product constants of their sulfide compounds (Lide, 1993). Hence, for sediments with [SEM]/[AVS] $>1, \mathrm{Ni}$ and $\mathrm{Zn}$ could be expected to be the trace metals that are present in relatively high concentrations in pore water and therefore to be more available for uptake by organisms. However, this condition is unlikely to apply to the surface sediments of Laizhou Bay and Zhangzi Island, because no [SEM]/[AVS] ratio exceeded 1 .

In the National Sediment Quality Survey Report to the U.S. Congress, the difference between the SEM and AVS molar concentrations in the sediment was one of the criteria to be used in assessing the quality of the sediment: a greater difference, [SEM]-[AVS], indicates a greater likelihood of metal toxicity (USEPA, 2004). Based on this criterion, each sediment sample fell into one of the following three categories; Category 1: adverse effects on aquatic life are probable; Category 2, adverse effects on aquatic life are possible; Category 3, no indication of adverse effects. The sediment sample was classified as Category 1 when $[\mathrm{SEM}]-[\mathrm{AVS}]>5$, Category 2 when $0<[\mathrm{SEM}]-[\mathrm{AVS}]<5$ and as Category 3 when [SEM]-[AVS] $<0$ (USEPA, 2004). Accordingly, all of the samples in this study had $[\mathrm{SEM}] /[\mathrm{AVS}]<1$ and therefore
[SEM]-[AVS] $<0$, putting them in sediment quality Category 3 , with no indication of associated adverse effects on aquatic life (Fig. 4c). The application of AVS-SEM method to evaluate the potential toxicity of sediment has the characteristics of simple operation, high efficiency and batch processing (Hsieh and Yang, 1989; Allen et al., 1993; Brouwer and Murphy, 1994). It is a widely used approach to predict the toxicity of sediment according to the relationship [SEM]/[AVS] or the difference between [SEM] and [AVS] (e.g. Di Toro et al., 1990, 1992; Allen et al., 1993; Ankley et al., 1996; Berry et al., 1996; Cooper and Morse, 1998; USEPA, 2004).

\section{Acknowledgements}

This study was co-supported by the Chinese Academy of Sciences (KZCX2-YW-JC203), the Department of Science and Technology of Shandong Province (2012GHY11535) and the CAS/SAFEA International Partnership Program for Creative Research Teams (Representative Environmental Processes and Resources Effects in Coastal Zones). C.T.A. Chen acknowledges the support from Taiwan's Aim for the Top University Program. This study is one of the pieces of research being performed under the 2011-2013 Scientific and Technological Bilateral Cooperation Program of the Chinese Academy of Sciences and the National Research Council of Italy.

\section{References}

Allen, H.E., Fu, G., Deng, B., 1993. Analysis of acid-volatile sulfide (AVS) and simultaneously extracted metals (SEM) for the estimation of potential toxicity in aquatic sediments. Environ. Toxicol. Chem. 12, 1441-1453.

Ankley, G., Thomas, N., Di Toro, D., Hansen, D., Mahony, J., Berry, W., Swartz, R., Hoke, R., Garrison, A., Allen, H., Zarba, C., 1994. Assessing potential bioavailability of metals in sediments: a proposed approach. Environ. Manage. 18, 331-337.

Ankley, G.T., Di Toro, D.M., Hansen, D.J., Berry, W.J., 1996. Technical basis and proposal for deriving sediment quality criteria for metals. Environ. Toxicol. Chem. 15, 2056-2066.

Balzer, W., 1989. Chemische reaktionen und Transportprozesse in oberflächennahen Sedimenten borealer und polarer Meeresgebiete. Habilitationsschrift, Christian-Albrechts-Universität zu Kiel, 312pp.

Berry, W.J., Hansen, D.J., Mahony, J.D., Robson, D.L., Di Toro, D.M., Shipley, B.P., Rogers, B., Corbin, J.M., Boothman, W.S., 1996. Predicting the toxicity of metalspiked laboratory sediments using acid-volatile sulfide and interstitial water normalizations. Environ. Toxicol. Chem. 15, 2067-2079.

Brouwer, H., Murphy, T.P., 1994. Diffusion method for the determination of acidvolatile sulfides (AVS) in sediment. Environ. Toxicol. Chem. 13, 1273-1275.

Cooper, D.C., Morse, J.W., 1998. Extractability of metal sulfide minerals in acidic solutions: application to environmental studies of trace metal contamination within anoxic sediments. Environ. Sci. Technol. 32, 1076-1078.

Di Toro, D.M., Mahony, J.D., Hansen, D.J., Scott, K.J., Hicks, M.B., Mayr, S.M., Redmond, M.S., 1990. Toxicity of cadmium in sediments: the role of acid volatile sulfide. Environ. Toxicol. Chem. 9, 1487-1502.

Di Toro, D.M., Mahony, J.D., Hansen, D.J., Scott, K.J., Carlson, A.R., Ankley, G.T., 1992. Acid volatile sulfide predicts the acute toxicity of cadmium and nickel in sediments. Environ. Sci. Technol. 26, 96-101.

Du, H., Huang, X.B., Huang, H.H., Zheng, B., Chen, W.Z., 2011. The spatiotemporal distribution of acid-volatile sulfide (AVS) and sulfate-reducing bacteria (SRB) in the surface deposits at Shen'ao Bay. Trans. Oceanol. Limnol., 85-93 (in Chinese).

Fang, T., Li, X.D., Zhang, G., 2005. Acid volatile sulfide and simultaneously extracted metals in the sediment cores of the Pearl River Estuary, South China. Ecotoxicol. Environ. Saf. 61, 420-431.

Gao, X.L., Chen, C.T.A., 2012. Heavy metal pollution status in surface sediments of the coastal Bohai Bay. Water Res. 46, 1901-1911.

Gao, X.L., Li, P.M., 2012. Concentration and fractionation of trace metals in surface sediments of intertidal Bohai Bay, China. Mar. Pollut. Bull. 64, 1529-1536.

Hansen, D.J., Berry, W.J., Boothman, W.S., Di Toro, D.M., Robson, D.L., 1996a. Predicting the toxicity of metal-contaminated field sediments using interstitial concentration of metals and acid-volatile sulfide normalizations. Environ. Toxicol. Chem. 15, 2080-2094.

Hansen, D.J., Mahony, J.D., Berry, W.J., Benyi, S.J., Corbin, J.M., Pratt, S.D., Di Toro, D.M., Abel, M.B., 1996b. Chronic effect of cadmium in sediments on colonization by benthic marine organisms: an evaluation of the role of interstitial cadmium and acid-volatile sulfide in biological availability. Environ. Toxicol. Chem. 15, 2126-2137.

Hsieh, Y.P., Shieh, Y.N., 1997. Analysis of reduced inorganic sulfur by diffusion methods: improved apparatus and evaluation for sulfur isotopic studies. Chem. Geol. 137, 255-261. 
Hsieh, Y.P., Yang, C.H., 1989. Diffusion methods for the determination of reduced inorganic sulfur species in sediments. Limnol. Oceanogr. 34, 1126-1130.

Hu, N.J., Liu, J.H., Huang, P., Shi, X.F., Zhu, A.M., Ma, D.Y., 2012. The distribution an risk assessment of metals in surface sediments of the Laizhou Bay in the Boha Sea. Acta Oceanol. Sinica 34, 92-100 (in Chinese).

Huo, W.Y., Li, Q.S., Ma, X.N., 2001. Study on Acid-volatile Sulfide (AVS) of Sediment in Mariculture Region of Jiaozhou Bay. Sci. Geogr. Sinica 21, 135-139 (in Chinese).

Jiang, Z.H., Ma, Q.M., Wang, X.L., Zhang, Y.Y., 2005. Study on the AVS in surface sediment in the North Area of the Bohai Bay. Mar. Environ. Sci. 24, 7-8, 43, (in Chinese).

Lasorsa, B., Casas, A., 1996. A comparison of sample handling and analytical methods for determination of acid volatile sulfides in sediment. Mar. Chem. 52, 211-220.

Lide, D.R.E., 1993. CRC Handbook of Chemistry and Physics, 74th ed. CRC Press, Baco Raton, pp. 1993-1994.

Lin, S., Huang, $K$, Chen, S, 2002. Sulfate reduction and iron sulfide minera formation in the southern East China Sea continental slope sediment. Deep-Sea Res. Part I 49, 1837-1852.

Liu, F., Wang, H.T., Wang, D.L., 2004. Spatial distributions of heavy metals from the Laizhou Bay littoral wetland. Adv. Mar. Sci. 22, 486-492 (in Chinese)

Long, E., Macdonald, D., Smith, S., Calder, F., 1995. Incidence of adverse biologica effects within ranges of chemical concentrations in marine and estuarine sediments. Environ. Manage. 19, 81-97.

Luoma, S.N., 1989. Can we determine the biological availability of sediment-bound trace elements? Hydrobiologia, 379-396.

Oehm, N.J. Luben, TJ. Ostrofsky, M.L, 1997. Spatial distribution of acid-volatile sulfur in the sediments of Canadohta Lake, PA. Hydrobiologia 345, 79-85.

Prica, M., Dalmacija, B., Rončević, S., Krčmar, D., Bečelić, M., 2008. A comparison of sediment quality results with acid volatile sulfide (AVS) and simultaneously extracted metals (SEM) ratio in Vojvodina (Serbia) sediments. Sci. Total Environ. 389, 235-244.

SEPA (State Environmental Protection Administration of China), 2002. Marine Sediment Quality (GB 18668-2002). Standards Press of China, Beijing (in Chinese).
Shepard, F.P., 1954. Nomenclature based on sand-silt-clay ratios. J. Sediment. Petrol. 24, 151-158.

Sun, W.W., Wang, D.Q., Chen, Z.L., Bi, C.J., Hu, B.B., Liu, Y.L., Li, J.F., Xu, S.Y., 2009 Contents and spatial distributiion of AVS and SEM in Wusong-Liuhe coasta sediments in Yangtze Estuary. Geochimica 38, 140-146 (in Chinese).

Sun, Y.D., Wang, D.Q., Chen, Z.L., Zhou, D., Bi, C.J., Li, J.F., Xu, S.Y., 2010, Spatial distribution of acid volatile sulfide (AVS) in sediments of Shanghai coastal zone. Mar. Environ. Sci. 29, 303-307 (in Chinese).

USEPA (United States Environmental Protection Agency), 2001. Methods for Collection, Storage and Manipulation of Sediments for Chemical and Toxicological Analyses: Technical Manual 2001. EPA-823-B-01002. Office of Science \& Technology, Office of Water: Washington, DC.

USEPA (United States Environmental Protection Agency), 2004. The Incidence and Severity of Sediment Contamination in Surface Waters of the United States, National Sediment Quality Survey. EPA 823-R-04-007, second ed. U.S. Environmental Protection Agency, Office of Water: Washington, DC.

van den Berg, G.A., Gustav Loch, J.P., van der Heijdt, L.M., Zwolsman, JJ.G., 1999 Mobilisation of heavy metals in contaminated sediments in the river Meuse, The Netherlands. Water, Air, Soil Pollut. 116, 567-586.

Wang, C.Y., Wang, X.L., 2007. Spatial distribution of dissolved $\mathrm{Pb}, \mathrm{Hg}, \mathrm{Cd}, \mathrm{Cu}$ and $\mathrm{As}$ in the Bohai Sea. J. Environ. Sci. 19, 1061-1066.

Wang, Q., Qu, K.M., Ma, S.A., Song, Y.L., 2008. Distribution and variation of AVS in the sediments of Rushan Bay. Mar. Fish. Res. 29, 102-107 (in Chinese).

Wilson, D.J., Chang, E., 2000. Bioturbation and oxidation of sulfide in sediments. J. Tenn. Acad. Sci. 75, 76-85.

Wu, Q.Q., Ma, O.M., Wang, J.G., Jiang, Z.H., Wang, X.L., 2007. The AVS in surface sediment of near sea area of Huanghe Estuary. Mar. Environ. Sci. 26, 126-129 (in Chinese).

Yu, K., Tsai, L., Chen, S., Ho, S., 2001. Chemical binding of heavy metals in anoxic river sediments. Water Res. 35, 4086-4094.

Yu, W.Q., Zhong, S.J., Pu, X.Q., Liu, F., 2009. Environmental responses of total organic carbon (TOC), acid volatile sulfide (AVS) and heavy metal elements in sediments of Licun Estuary in Jiaozhou Bay. J. Palaeogeogr. 11, 338-347 (in Chinese). 